\title{
Pengaruh Media Sosial terhadap Partisipasi Pemilih Pemula pada Pemilihan Presiden 2019: Studi Pada Mahasiswa FISIPOL UGM
}

\author{
Ahmad Nurcholis ${ }^{1} \&$ Tri Rizki Putra ${ }^{2}$
}

\begin{abstract}
Abstrak
Penelitian ini menganalisis pengaruh media sosial terhadap partisipasi pemilih pemula pada pemilihan presiden 2019 yang difokuskan kepada mahasiswa FISIPOL UGM. Seiring dengan perkembangan teknologi, media sosial semakin masif digunakan sebagai saluran informasi dalam berbagai bidang. Di bidang politik, media sosial memberikan peran yang sangat signifikan terhadap para pemilih, khususnya pemilih pemula pada Pemilihan Umum (Pemilu) 2019. Setiap pasangan calon menyebarkan informasinya lewat media sosial dengan harapan mendapatkan dukungan dan simpati. Penelitian ini menggunakan metode kuantitatif deskriptif dengan melakukan survei online melalui penyebaran google form kepada mahasiswa Fisipol UGM. Teori yang digunakan dalam penelitian ini yaitu teori tentang pemilih pemula, Teori Stimulus Organisme Respons (SOR), dan teori tentang partisipasi politik. Hasil penelitian menunjukkan bahwa pemilih pemula aktif menggunakan media sosial dan menjadikan media sosial sebagai sumber informasi utama. Lebih kurang, pemilih pemula adalah pemilih yang paling berpengaruh dalam perebutan suara, khususnya melalui kampanye di media sosial. Pemilih pemula cenderung memilih pasangan yang aktif memberikan informasi lewat media sosial karena dianggap menarik dan mudah dijangkau.
\end{abstract}

Kata kunci: Media sosial; pemilih pemula; pemilu

1 Mahasiswa Departemen Politik dan Pemerintahan, Fakultas Ilmu Sosial dan Ilmu Politik, Universitas Gadjah Mada.

2 Mahasiswa Departemen Politik dan Pemerintahan, Fakultas Ilmu Sosial dan Ilmu Politik, Universitas Gadjah Mada. 


\section{PENDAHULUAN}

Sebagai negara yang menganut paham demokrasi, Indonesia sudah tidak asing lagi dengan Pemilihan Umum (Pemilu), khususnya dalam pemilihan Presiden dan Wakil Presiden. Pemilu yang demokratis telah dilangsungkan sejak tahun 1955 dan masih aktif hingga saat ini. Keberlangsungan Pemilu yang dilaksanakan tiap 5 tahun sekali menjadi sebuah pesta bagi hampir seluruh lapisan masyarakat Indonesia. Masyarakat sebagai aktor utama dalam Pemilu menjadi sebuah perhatian besar dimulai dari kontestasi para calon hingga keberlangsungan Pemilu itu sendiri, yang meliputi segala level pemilihan baik di tingkat daerah maupun di tingkat nasional. Kampanye dari masing-masing calon juga merupakan suatu hal yang penting dalam mempengaruhi preferensi memilih masyarakat.

Penelitian ini ingin melihat dinamika dibalik pengaruh penggunaan media sosial terhadap partisipasi pemilih pemula pada pemilihan presiden 2019. Fokus penelitian ini berada di mahasiswa Fakultas Ilmu Sosial dan Politik, Universitas Gadjah Mada (FISIPOL UGM). Tema ini menarik untuk diteliti karena beberapa tahun ke belakang jumlah penggunaan media sosial terus melonjak pesat, tak terkecuali di Indonesia. Semakin maraknya penggunaan media sosial di Indonesia berimplikasi nyata di berbagai bidang, baik dari bidang kesehatan, olahraga, maupun politik. Fenomena ini dimanfaatkan dengan sangat baik oleh calon presiden dan calon wakil presiden untuk menyampaikan gagasan yang mereka bawa pada pemilihan presiden 2019. Hal ini diaplikasikan dengan model kampanye yang digunakan 
para calon tidak lagi semata-mata hanya menyampaikan orasi di lapangan luas, tetapi seiring dengan penggunaan media sosial di Indonesia yang melonjak sangat cepat, para calon dapat menyampaikan kampanyenya di dalam sebuah ranah yang baru, yaitu melalui media sosial.

Merujuk pada Pemilu 2019, salah satu hal yang paling banyak diperbincangkan adalah partisipasi pemilih millenial. Hampir sebagian dari pemilih milenial merupakan pemilih pemula pada Pemilu 2019. Secara umum, pemilih pemula merupakan suatu golongan yang baru pertama kali berpartisipasi dalam Pemilu. Hal ini dikarenakan bahwa mereka baru menerima Kartu Tanda Penduduk (KTP) sebagai syarat untuk memperoleh hak memilih. Pemilih pemula tidak jarang dianggap sebelah mata suaranya karena produksi pengetahuan politik yang masih awam dan diasumsikan relatif tidak sebanding dengan pemilih yang sudah berusia matang. Namun, pada Pemilu 2019 suara pemilih pemula justru menjadi perhitungan bagi para calon karena jumlah pemilih pemula yang relatif besar, yaitu sampai menyentuh angka 14 juta pemilih. Dengan produksi pengetahuan politik yang masih awam, pemilih pemula terkesan mudah untuk dipengaruhi preferensi memilih politiknya. Ditambah fakta bahwa kebanyakan para calon saat ini menyampaikan kampanyenya melalui media sosial, tentu merupakan suatu hal yang beririsan karena media sosial sendiri kebanyakan diakses oleh para milenial, khususnya para pemilih pemula.

Seiring dengan perkembangan teknologi informasi berbasis internet, maka semakin penting peran media sosial online sebagai salah 
satu faktor yang dapat memberikan efek positif dalam partisipasi politik pemilih pemula di dalam Pemilihan Presiden 2019. Media sosial saat ini memiliki banyak jenisnya mulai dari twitter, facebook, instagram, dan sebagainya. Dengan banyaknya media sosial, maka masyarakat khususnya generasi muda dapat dengan bebas menentukan pilihan media sosial untuk keperluan hiburan dan komunikasi. Hal ini bisa dilihat dari pengguna aktif media sosial di Indonesia yang relatif besar dengan jumlah 79 juta pengguna aktif. Banyaknya pengguna media sosial di Indonesia membuktikan bahwa media sosial masih menjadi andalan sebagian besar masyarakat Indonesia guna sebagai media hiburan ataupun komunikasi (Harsan, Prasetyo, \& Pujiyana, 2019).

Akibat dari banyaknya penggunaan media sosial di Indonesia banyak konten tentang politik yang tersebar di media sosial. Di media sosial, komunikasi bisa tersebar melalui individu atau kelompok sehingga informasi bisa cepat menyebar secara luas. Hal inilah yang menyebabkan banyak politisi memanfaatkan media sosial sebagai platform untuk mempopulerkan namanya atau biasa disebut kampanye. Selain itu, sebagian besar media massa memanfaatkan media sosial sebagai alat untuk menyebarkan artikel atau konten beritanya untuk dinikmati oleh konsumen. Semakin mudahnya mengakses sosial media maka semakin mudah setiap masyarakat dalam mendapatkan konten mengenai politik dan secara langsung akan berpengaruh pada dirinya.

Media sosial juga sangat efektif digunakan sebagai media komunikasi khususnya dalam memberikan informasi dan menerima feedback dari para politisi. Ini dapat mendekatkan dan merapatkan 
hubungan antara para politisi dengan masyarakat. Terlebih lagi saat ini, penggunaan media sosial dikalangan masyarakat semakin populer dan berkembang, hingga ke pelosok pedesaan. Sehingga dengan formula informasi yang baik, masyarakat akan mudah memahami pesan-pesan politik yang disampaikan oleh para politisi. Pada akhirnya, melalui penyampaian pesan-pesan politik yang tepat dan dilakukan secara efektif akan mampu menarik simpati masyarakat sehingga mereka akan menerima maksud yang diinginkan oleh para politisi (Peranginangin \& Zainal, 2018).

\section{TEORI PEMILIH PEMULA}

Pemilih pemula memiliki beberapa pengertian yang saat ini digunakan. Ada tiga kategori pemilih pemula di Indonesia. Pertama, pemilih yang rasional, yakni pemilih yang benar-benar memilih partai berdasarkan penilaian dan analisis mendalam (Rachmat \& Esther, 2016). Kedua, pemilih kritis emosional, yakni pemilih yang masih idealis dan tidak kenal kompromi (Rachmat \& Esther, 2016). Ketiga, pemilih pemula, yakni pemilih yang baru pertama kali memilih karena usia mereka baru memasuki usia pemilih (Rachmat \& Esther, 2016). Dalam penelitian ini yang digunakan pengertian sebagai pemilih pemula adalah pemilih yang baru pertama kali memilih karena usia mereka baru memasuki usia pemilih. Di Indonesia warga negara yang berhak memilih adalah warga negara yang telah genap berumur 17 tahun. Dalam UU No. 10 Tahun 2008 pasal I ayat (22) dijelaskan bahwa pemilih adalah warga negara Indonesia yang telah genap berumur tujuh 
belas tahun atau lebih atau sudah/belum kawin. Kemudian ada pasal 19 ayat (I dan 2) UU No. 10 Tahun 2008 yang menerangkan bahwa pemilih yang mempunyai hak memilih adalah warga negara Indonesia yang didaftar oleh penyelenggara Pilkada dalam daftar pemilih dan pada hari pemungutan suara telah genap berumur tujuh belas tahun atau lebih atau sudah pernah kawin. Pemilih pemula di Indonesia yang dalam artian sebagai pemilih yang baru memasuki usia pemilih tujuh belas tahun berjumlah sangat banyak dan dapat diperhitungkan dalam setiap penyelenggaraan pemilu.

\section{TEORI STIMULUS ORGANISME RESPON (SOR)}

Teori Stimulus Organisme Respon (SOR) pertama kali dijelaskan oleh ditemukan oleh Hovland, yang awalnya berasal dari psikologi, namun diiringi dengan perkembangan zaman, teori ini juga digunakan dalam ilmu komunikasi. Menurut Teori SOR, dalam proses komunikasi, berkaitan dengan perubahan sikap adalah aspek how bukan what atau why. Jelasnya, teori ini berusaha mendefinisikan how to communicate atau dalam hal ini how to change the attitude. Dalam proses perubahan sikap, terlihat bahwa sikap bisa berubah, hanya jika dorongan yang menerpa benar-benar melebihi semula. Dalam memahami sikap yang baru ada, tiga variabel yang penting yaitu perhatian, pengertian, dan penerimaan. Hal mendasar dalam teori ini lebih kepada pesan yang disampaikan mampu memberikan motivasi, menumbuhkan gairah kepada individu sehingga individu cepat menerima pesan yang didapat dan selanjutnya terjadi perubahan sikap perilaku. Informasi yang 
diterima individu dari berbagai macam sumber, misal media sosial, dapat mempengaruhi pola pikir dan posisi mereka dalam menerima informasi tersebut. Unsur penting dalam model Teori SOR itu ada tiga yaitu: Pesan (Stimulus, S), Individu (Organisme, O) dan Efek (Respon, $\mathrm{R})$.

\section{TEORI PARTISIPASI POLITIK}

Partisipasi politik memiliki beragam pengertian. Semua pengertian yang ada mencoba menjelaskan apa itu partisipasi politik sesuai dengan pendapatnya masing-masing. Menurut Ramlan Surbakti yang dimaksud dengan partisipasi politik adalah keikutsertaan warga negara biasa dalam menentukan segala keputusan yang menyangkut atau mempengaruhi hidupnya (Subekti, 2014). Sastroatmodjo (1995) juga berpendapat bahwa partisipasi politik pada dasarnya merupakan kegiatan yang dilakukan warga negara untuk terlibat dalam proses pengambilan keputusan dengan tujuan untuk mempengaruhi pengambilan keputusan yang dilakukan pemerintah (Febriantanto, 2019). Sedangkan Miriam Budiardjo (Sastroatmodjo, 1995) mendefinisikan partisipasi politik adalah kegiatan seseorang atau kelompok orang untuk ikut serta secara aktif dalam kehidupan politik, yaitu dengan jalan memilih pimpinan negara dan secara langsung atau tidak langsung mempengaruhi kebijakan pemerintah (Febriantanto, 2019). Sementara menurut Febriantanto partisipasi politik adalah keterlibatan individu atau kelompok sebagai warga negara dalam proses politik yang berupa kegiatan yang positif dan dapat juga yang 
negatif yang bertujuan untuk berpartisipasi aktif dalam kehidupan politik (2019). Apabila dikaitkan dengan Pemilu sebagai kegiatan politik, maka partisipasi pemilih dikatakan bahwa keterlibatan individu atau kelompok sebagai warga negara bertujuan untuk memberikan hak suaranya dalam pemilu (Febriantanto, 2019). Dari beberapa pengertian tersebut bisa disimpulkan mengenai pengertian partisipasi politik. Secara umum partisipasi politik merupakan bentuk kegiatan masyarakat sebagai warga negara dalam bentuk kegiatan politik yang berpengaruh positif atau negatif kepada negara dan masyarakat pada umumnya.

Selanjutnya, Febriantanto juga menyebutkan ada beberapa bentuk dari partisipasi politik. Seperti yang disebutkan di atas bahwa partisipasi politik jika dikaitkan dengan Pemilu maka pengertiannya adalah kegiatan masyarakat memberikan hak suaranya, maka partisipasi politik tersebut bisa disebut partisipasi politik konvensional. Hal tersebut sesuai dengan partisipasi politik yang dikemukakan oleh Almond (Mas'oed, 2011) yang menerangkan bahwa pemberian suara dalam pemilu dan pilkada termasuk dalam salah satu bentuk partisipasi politik, khususnya partisipasi politik konvensional (Febriantanto, 2019). Lebih lanjut, Almond (Mas'oed, 2011) membedakan bentuk partisipasi politik, yaitu partisipasi politik konvensional dan nonkonvensional. Bentuk partisipasi politik konvensional merupakan bentuk yang lazim dan dapat berupa pemberian suara, diskusi politik, kegiatan kampanye, bergabung dengan kelompok kepentingan, maupun komunikasi individu dengan pejabat politik administratif. Sedangkan bentuk 
partisipasi non konvensional merupakan bentuk yang tidak lazim berupa pengajuan petisi berdemonstrasi, konfrontasi, mogok, maupun tindak kekerasan politik (Febriantanto, 2019).

\section{METODE PENELITIAN}

Penelitian ini menggunakan metode penelitian yang bersifat deskriptif kuantitatif, yakni dengan menggambarkan bagaimana pengaruh media sosial dalam partisipasi pemilih pemula pada Pemilihan Presiden tahun 2019.

Penelitian ini berfokus pada mahasiswa FISIPOL UGM khususnya yang menjadi pemilih pemula pada saat Pemilihan Presiden tahun 2019. Mahasiswa berasal dari lima departemen yang ada di FISIPOL UGM yaitu, Hubungan Internasional, Politik Pemerintahan, Sosiologi, Manajemen Kebijakan Publik, dan Ilmu Komunikasi. Sumber data yang digunakan dalam penelitian ini didapatkan melalui survey online dengan menggunakan google form yang disebarkan melalui pesan singkat, LINE. Data yang diperoleh sejumlah 60 responden yang berasal dari lima departemen dengan jumlah yang bervariasi.

Analisis data dilakukan melalui cara membandingkan realitas data dengan teori yang digunakan. Analisis data dalam penelitian ini dilakukan dengan cara deskriptif kuantitatif untuk menganalisa data dengan cara membandingkan hasil data yang diperoleh dan mengkonversikan dalam bentuk data kuantitatif yang selanjutnya akan dideskripsikan fenomena yang terjadi berdasar data tersebut. Hasil penelitian disusun dengan kata-kata dan kalimat yang dijadikan sebagai 
jawaban atas fenomena yang diteliti. Analisis data yang digunakan dalam penelitian ini bersifat kuantitatif, dengan memasukkan data yang kemudian dianalisis dan ditarik sebuah kesimpulan.

\section{EKSISTENSI PEMILIH PEMULA}

Dalam Pemilu 2019, suara pemilih pemula kerap menjadi perbincangan di masyarakat. Hal ini terjadi bukan karena tanpa alasan, sebab berdasarkan hasil survei yang dilakukan oleh Kependudukan dan Pencatatan Sipil (Dukcapil) Kemendagri menunjukkan bahwa jumlah pemilih pemula pada Pemilu 2019 hampir mencapai 14 juta jiwa (Koran Sindo, 2017). Tentu itu bukan merupakan angka yang kecil di dalam kontestasi politik elektoral, khususnya di Indonesia. Dengan jumlah yang tinggi tersebut, berbagai pihak mewanti-wanti agar pemilih pemula memanfaatkan suara yang dimilikinya untuk memilih sebijak-bijaknya. Sosialisasi terkait anti golongan putih (golput) yang dilakukan Pemerintah terus digaungkan secara masif untuk mencegah terbuang sia-sianya suara dari pemilih pemula ini.

Hasil penelitian menunjukkan bahwa terdapat sekitar 90\% atau 54 responden yang merupakan mahasiswa aktif FISIPOL UGM baru pertama kali memilih atau merupakan pemilih pemula pada Pemilu 2019, sedangkan sekitar 10\% atau 6 responden sisanya bukan merupakan pemilih pemula pada Pemilu 2019. Data secara rinci dapat dilihat pada diagram di bawah ini: 
Tabel 1. Eksistensi Pemilih Pemula

\begin{tabular}{|c|c|c|c|c|}
\hline Valid & Frequency & Percent & $\begin{array}{c}\text { Valid } \\
\text { Percent }\end{array}$ & $\begin{array}{c}\text { Cumulative } \\
\text { Percent }\end{array}$ \\
\hline Tidak & 6 & 10.0 & 10.0 & 10.0 \\
\hline Ya & 54 & 90.0 & 90.0 & 100.0 \\
\hline Total & 60 & 100.0 & 100.0 & \\
\hline
\end{tabular}

Diagram 1: Eksistensi Pemilih Pemula
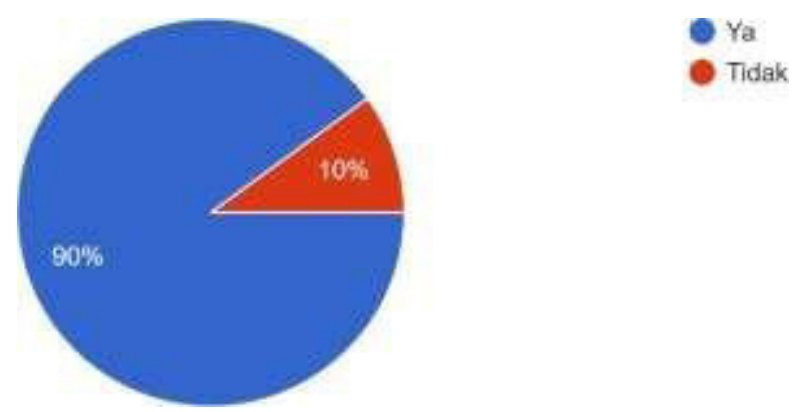

Tidak

Dari hasil tersebut menunjukkan bahwa hampir seluruh mahasiswa aktif FISIPOL UGM merupakan pemilih pemula. Data ini diperkuat dengan rata-rata umur mahasiswa aktif FISIPOL UGM berkisar pada umur 17-21 tahun. Tentu ini merupakan rata-rata umur pemilih pemula secara nasional. Hasil dari data tersebut juga menunjukkan bahwa angka eksistensi pemilih pemula masih tinggi, khususnya di kalangan mahasiswa.

\section{SUMBER INFORMASI PEMILIH PEMULA}

Informasi dari Calon Presiden dan Wakil Presiden merupakan hal yang sangat penting untuk diketahui oleh para pemilih, khususnya 
pemilih pemula karena sebagian besar pemilih pemula masih minim produksi pengetahuan politiknya. Minimnya produksi pengetahuan politik pemilih pemula berimplikasi pada preferensi memilih mereka di dalam Pemilu. Namun saat ini, informasi bisa didapatkan secara mudah dari berbagai sumber yang ada (Lukman, Priyatna \& Sani, 2017).

Pada pertanyaan berikutnya, responden diminta untuk memilih tiga sumber yang paling berpengaruh dalam mendapat informasi Calon Presiden dan Wakil Presiden pada Pemilu 2019. Hasil penelitian menunjukkan bahwa media sosial menjadi urutan pertama sebagai sumber untuk mendapatkan informasi Calon Presiden dan Wakil Presiden pada Pemilu 2019 dengan angka sekitar 95\% atau 57 responden, diikuti televisi dengan angka $73,3 \%$ atau 44 responden, keluarga $48,3 \%$ atau 29 responden dan lain-lainnya dapat dilihat pada diagram di bawah ini:

\section{Diagram 2. Informasi Pemilih Pemula}

Darimanakah Anda mendapatkan informasi Calon Presiden dan Wakil Presiden pada Pemilu 2019? (Mohon pilih tiga hal yang Anda anggap paling berpengaruh) 50 tanggapan

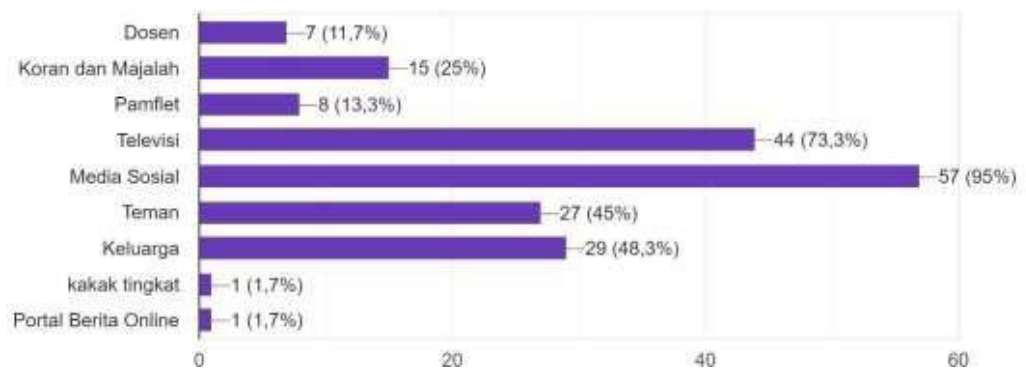


Diagram di atas menunjukkan bahwa media sosial menjadi sumber paling banyak digunakan oleh para pemilih pemula untuk mendapatkan informasi mengenai Calon Presiden dan Wakil Presiden. Temuan tersebut memberikan informasi bahwa media sosial menjadi ranah baru bagi para pemilih, khususnya pemilih pemula dengan pasangan calon yang berkontestasi. Ini bertambah jelas dengan fakta bahwa rata-rata dari pengguna media sosial adalah kaum milenial atau yang dalam konteks ini pemilih pemula. Fakta tersebut dimanfaatkan pasangan calon untuk menarik suara dari pemilih pemula dengan cara memperbanyak kampanye yang disebarluaskan melalui media sosial. Tentu ini merupakan titik temu yang sangat menguntungkan bagi para pasangan calon dengan mengeluarkan dana yang tidak terlalu banyak, tapi berimplikasi sangat signifikan kepada mereka.

\section{MEDIA SOSIAL: MEMPERMUDAH PEROLEHAN INFORMASI}

Seiring dengan semakin berkembangnya teknologi, kemudahan dalam mendapat informasi juga mengalami perkembangan yang pesat, termasuk dalam mendapatkan informasi politik. Media sosial menjadi salah satu hasil dari berkembangnya teknologi. Hadirnya media sosial bisa semakin mempermudah akses informasi bagi masyarakat, khususnya pemilih pemula karena mampu dijangkau hampir seluruh lapisan masyarakat secara tidak terbatas.

Dengan banyaknya informasi dari Calon Presiden dan Wakil Presiden yang diperoleh melalui media sosial, selanjutnya responden 
diminta menjawab apakah media sosial memudahkan mereka dalam memperoleh informasi dari Calon Presiden dan Wakil Presiden. Hasil penelitian menunjukkan bahwa hampir seluruh responden setuju bahwa media sosial dapat mempermudah informasi dari pasangan calon. Hal ini dibuktikan dengan angka yang mencapai $98,3 \%$ atau 59 responden yang menjawab "ya", artinya hanya ada 1,7\% atau 1 responden yang tidak setuju bahwa media sosial mampu memudahkan mereka dalam memperoleh informasi dari pasangan calon yang berkontestasi. Data secara rinci dapat dilihat pada diagram di bawah ini:

Tabel 2. Media Sosial: Mempermudah Perolehan Informasi

\begin{tabular}{|c|c|c|c|c|}
\hline Valid & Frequency & Percent & $\begin{array}{c}\text { Valid } \\
\text { Percent }\end{array}$ & $\begin{array}{c}\text { Cumulative } \\
\text { Percent }\end{array}$ \\
\hline Tidak & 1 & 1.7 & 1.7 & 1.7 \\
\hline Ya & 59 & 98.3 & 98.3 & 100 \\
\hline Ya & 60 & 100 & 100 & \\
\hline
\end{tabular}

Diagram 3. Media Sosial: Mempermudah Perolehan Informasi

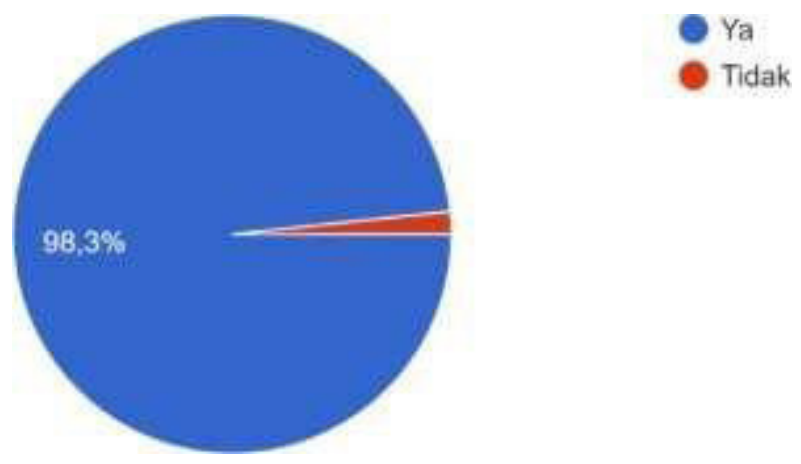


Dari hasil tersebut menunjukkan bahwa media sosial dengan signifikan mampu memudahkan para pemilih pemula dalam memperoleh informasi dari pasangan calon. Dengan kemudahan informasi yang didapat, bisa merepresi angka pemilih golput kedepannya, khususnya para pemilih pemula yang sudah dijelaskan sebelumnya bahwa produksi pengetahuan politiknya masih awam atau masih sebatas di atas permukaan saja. Namun dengan tersebarnya informasi terkait pasangan calon di media sosial, pemilih pemula juga tetap harus bijak dalam mengamati informasi yang didapat karena tidak semua informasi yang ada di media sosial benar adanya. Oknumoknum yang tidak bertanggung jawab bisa masuk ke ranah ini dengan menyebar informasi kebencian kepada salah satu pasangan calon yang menjadi pesaingnya. Media sosial bisa mempermudah mendapatkan informasi pasangan calon namun di sisi lain media sosial juga bisa menjerumuskan seseorang kepada informasi yang kurang valid dan juga bisa mengandung ujaran kebencian.

\section{KAMPANYE DI MEDIA SOSIAL}

Berdasar pembahasan sebelumnya bisa dikatakan bahwa media sosial telah mendapatkan tempat bagi sebagian besar responden. Dengan banyaknya masyarakat mengakses media sosial, maka komunikasi antar personal bisa dengan mudah dilakukan oleh masyarakat. Termasuk dalam hal ini pasangan calon bisa memanfaatkan media sosial sebagai alat dalam berkomunikasi secara visual dengan masyarakat secara luas atau biasa disebut sebagai kampanye. Kampanye melalui media sosial 
merupakan salah satu cara dalam upaya menekan anggaran kampanye dan secara pelaksanaan lebih mudah dilakukan (Abidin, Khoerunnisa, \& Ma’arif, 2018). Selain itu, banyaknya para pemilih pemula yang mengakses media sosial menjadikan salah satu keuntungan lain yang bisa di dapat bagi pasangan calon dengan mereka berkampanye melalui media sosial.

Pada bagian selanjutnya dalam tulisan ini, pertanyaan selanjutnya kepada responden adalah mengenai keterlibatan mereka melihat kampanye Calon Presiden dan Wakil Presiden di Media Sosial. Data menunjukkan bahwa hampir seluruh responden menjawab pernah melihat kampanye Calon Presiden dan Wakil Presiden di media sosial dengan persentase sebesar $98,8 \%$ atau sebanyak 59 responden. Sementara hanya ada sejumlah satu responden atau dengan persentase hanya $1.7 \%$ atau 1 responden yang menjawab tidak pernah melihat kampanye Calon Presiden dan Wakil Presiden di Media Sosial. Data secara rinci dapat dilihat pada diagram di bawah ini:

Tabel 3. Kampanye di Media Sosial

\begin{tabular}{|c|c|c|c|c|}
\hline Valid & Frequency & Percent & $\begin{array}{c}\text { Valid } \\
\text { Percent }\end{array}$ & $\begin{array}{c}\text { Cumulative } \\
\text { Percent }\end{array}$ \\
\hline Tidak & 1 & 1.7 & 1.7 & 1.7 \\
\hline Ya & 59 & 98.3 & 98.3 & 100.0 \\
\hline Total & 60 & 100.0 & 100.0 & \\
\hline
\end{tabular}




\section{Diagram 4. Kampanye di Media Sosial}
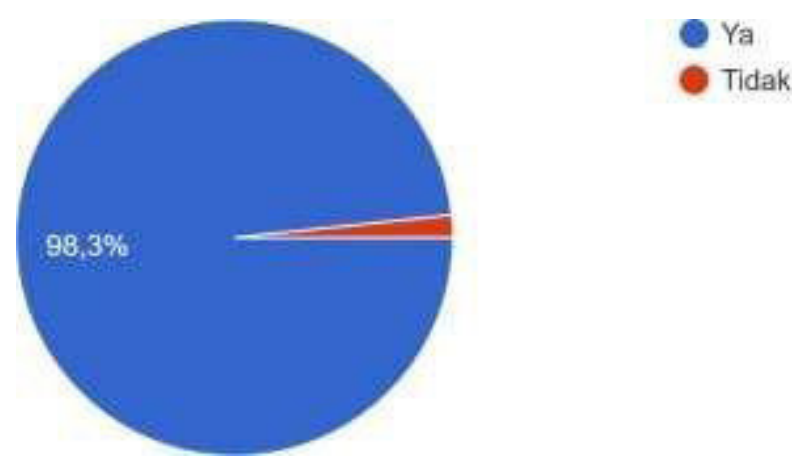

Hasil tersebut menunjukkan bahwa para pasangan calon telah berhasil memanfaatkan media sosial sebagai alat dalam berkampanye. Terbukti bahwa hampir seluruh responden telah melihat kampanye pasangan calon di media sosial. Tentu ini merupakan suatu keuntungan bagi para pasangan calon karena seiring dengan berkembangnya teknologi, terjadi pula perubahan pola kampanye yang dilakukan para pasangan calon. Dulu kampanye dilakukan dengan kerja keras yang menguras keringat, misalnya melakukan orasi dengan toa di depan orang banyak, sedangkan sekarang kampanye bisa dilakukan di ranah baru yang tetap mampu menghasilkan output yang tak kalah signifikan dengan pola kampanye yang dahulu. Sekarang kampanye tidak memerlukan tenaga berlebih dalam menyebarluaskannya, para pasangan calon hanya butuh lebih kreatif untuk membagikan kampanye melalui media sosial. Kampanye yang menarik diharuskan dalam penyebarannya, hal ini ditujukan agar para pemilih pemula lebih menaruh perhatian atas apa yang mereka lihat. 


\section{MEDIA SOSIAL PALING POPULER}

Lebih dari 3.5 miliar manusia di bumi bergabung ke media sosial, menurut laporan terbaru We Are Social dan Hootsuite pada bulan Juli 2019 (Pertiwi, 2019). Hal ini merupakan jumlah yang sangat besar dan menjadi bukti bagaimana perkembangan media sosial yang begitu pesat. Perkembangan media sosial ini juga diikuti dengan banyaknya media sosial yang bermunculan dan dapat dimanfaatkan oleh masyarakat secara luas. Sampai sekarang setidaknya ada enam media sosial yang biasa digunakan di Indonesia yaitu Facebook, Instagram, LINE, Twitter, Whatsapp, dan Youtube. Semua media sosial ini juga menjadi tempat bagi para Calon Presiden dan Wakil Presiden dalam menggencarkan kampanyenya. Seperti disampaikan dalam pembahasan sebelumnya bahwa kampanye melalui media sosial menjadi efektif karena murah biaya dan dapat menjangkau masyarakat secara luas.

Pertanyaan selanjutnya responden diminta untuk memilih di media sosial manakah yang paling mereka sering melihat kampanye Calon Presiden dan Wakil Presiden pada Pemilu 2019. Hasil penelitian menunjukkan Instagram menjadi peringkat teratas sebagai media sosial yang paling banyak ditemukan kampanye dari pasangan calon dengan angka 53,3\% atau sebanyak 32 responden, diikuti Twitter dan Youtube dengan angka $21,7 \%$ atau 13 responden dan $11,7 \%$ atau 7 responden. Data secara rinci dapat dilihat pada diagram di bawah ini: 
Tabel 4. Media Sosial Paling Populer

\begin{tabular}{|c|c|c|c|c|}
\hline Valid & Frequency & Percent & $\begin{array}{c}\text { Valid } \\
\text { Percent }\end{array}$ & $\begin{array}{c}\text { Cumulative } \\
\text { Percent }\end{array}$ \\
\hline Facebook & 1 & 1.7 & 1.7 & 1.7 \\
\hline Instagram & 32 & 53.3 & 53.3 & 55.0 \\
\hline LINE & 5 & 8.3 & 8.3 & 63.3 \\
\hline Twitter & 13 & 21.7 & 21.7 & 85.0 \\
\hline Whatsapp & 2 & 3.3 & 3.3 & 88.3 \\
\hline Youtube & 7 & 11.7 & 11.7 & 100.0 \\
\hline Total & 60 & 100.0 & 100.0 & \\
\hline
\end{tabular}

\section{Diagram 5. Media Sosial Paling Populer}
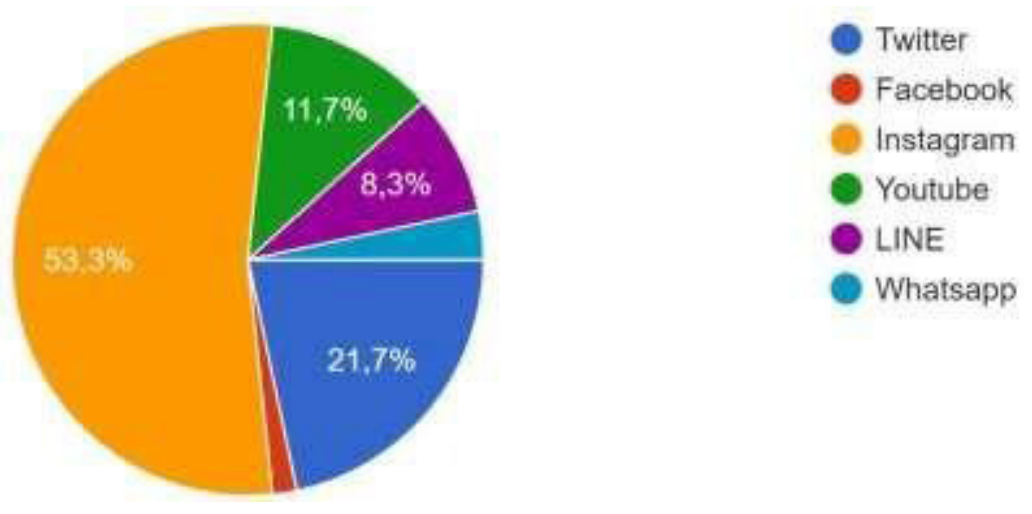

Hasil data di atas menunjukkan bahwa Instagram menjadi platform favorit ditemukannya kampanye dari pasangan calon. Hal ini ditambah fakta pengguna aktif Instagram harian mencapai 400 juta orang (Winarso, 2017). Itu membuktikan bahwa Instagram banyak digunakan dan diterima oleh masyarakat di seluruh dunia termasuk di Indonesia. Lagi-lagi hal ini dimanfaatkan oleh para pasangan calon untuk menyebarluaskan kampanye guna mengambil suara dari 
kaum milenial. Kaum milenial yang merupakan pemilih pemula dan pengguna aktif Instagram juga dapat dijangkau oleh para pasangan calon secara mudah. Cukup dengan membuat akun Instagram dan mem-posting foto atau video yang berkaitan dengan kampanye, para pasangan dapat dengan "praktis" masuk ke beranda para pemilih, khususnya pemilih pemula. Bahkan jika para pemilih pemula tersebut tidak berniat untuk melihat kampanye dari para pasangan calon, foto atau video yang diposting pasangan calon tetap dapat berada di beranda Instagram mereka yang masuk melalui kolom explore yang secara otomatis telah disetting instagram.

\section{MEDIA SOSIAL DAN PREFERENSI MEMILIH}

Dalam kerangka teori dijabarkan mengenai Teori Stimulus Organisme Respon (SOR) yang memiliki konsep berupa pesan yang disampaikan mampu memberikan motivasi dan menumbuhkan gairah kepada individu sehingga individu cepat menerima pesan yang didapat dan selanjutnya terjadi perubahan sikap perilaku. Perilaku individu bisa dipengaruhi oleh sebuah pesan atau visual yang disampaikan secara menarik. Begitu pula dengan keberadaan kampanye pasangan calon Presiden dan Calon Presiden yang berupa konten pesan atau kerangka visual yang dibuat secara menarik dan diharapkan bisa mempengaruhi preferensi memilih para pemilih yang melihat konten kampanye tersebut. Seperti yang telah dibahas sebelumnya bahwa kampanye para pasangan calon banyak disebar melalui media sosial, sehingga di media 
sosial terdapat kampanye pasangan calon berupa pesan atau kerangka visual yang bisa mempengaruhi preferensi memilih.

Pada bagian ini responden diberi pertanyaan mengenai apakah kampanye Calon Presiden dan Wakil Presiden di Media Sosial dapat mempengaruhi preferensi memilih responden. Jawaban yang muncul dari responden ternyata tidak semuanya terpengaruh kampanye pasangan calon di media sosial. Responden yang menyatakan kampanye pasangan calon di media sosial dapat mempengaruhinya dalam menentukan preferensi pilihannya sekitar $70 \%$ atau berjumlah 42 responden. Sementara di sisi lain responden yang menjawab bahwa kampanye pasangan calon di media sosial tidak mempengaruhi dia dalam menentukan preferensi pilihannya sekitar 30\% atau berjumlah 18 responden. Data secara rinci dapat dilihat pada diagram di bawah ini:

Tabel 5. Media Sosial dan Preferensi Memilih

\begin{tabular}{|c|c|c|c|c|}
\hline Valid & Frequency & Percent & $\begin{array}{c}\text { Valid } \\
\text { Percent }\end{array}$ & $\begin{array}{c}\text { Cumulative } \\
\text { Percent }\end{array}$ \\
\hline TIdak & 18 & 30.0 & 30.0 & 30.0 \\
\hline Ya & 42 & 70.0 & 70.0 & 100.0 \\
\hline Total & 60 & 100.0 & 100.0 & \\
\hline
\end{tabular}




\section{Diagram 6. Media Sosial dan Preferensi Memilih}

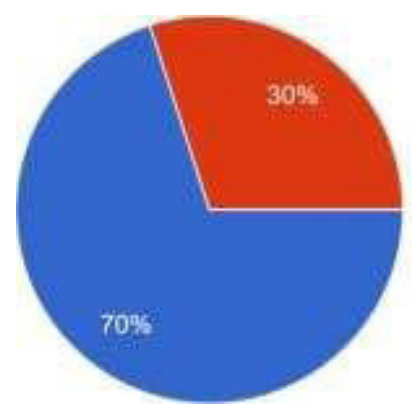

Data di atas bisa menunjukkan bahwa pemilih pemula masih bisa terpengaruh oleh adanya kampanye di media sosial yang dilakukan oleh pasangan calon. Hasil penelitian sejumlah 70\% responden yang terpengaruh kampanye Calon Presiden dan Wakil Presiden di media sosial dalam menentukan preferensi memilihnya merupakan jumlah yang banyak. Pemilih pemula yang baru memasuki usia hak pilih juga belum memiliki jangkauan politik yang luas, untuk menentukan kemana mereka harus memilih (Rachmat \& Esther, 2016). Alasan tersebut yang menyebabkan para pemilih pemula masih sangat dengan mudah untuk terpengaruhi khususnya terpengaruh kampanye di media sosial yang dilakukan oleh pasangan calon. Data tersebut bisa membuktikan bahwa sebagian besar para pemilih pemula masih sangat bisa terpengaruh kampanye di media sosial yang dilakukan oleh pasangan calon. Hal ini tentu menjadi fakta menarik bagi kondisi politik di Indonesia, sebab untuk kedepannya dalam metode kampanye bisa dengan memaksimalkan bentuk kampanye di media sosial. 
Pada bagian berikutnya responden di suguhkan pernyataan dan diminta untuk menanggapi pernyataan dengan skala angka 1-4. Angka 1 menunjukkan tanggapan sangat setuju, angka 2 menunjukkan tanggapan setuju, angka 3 menunjukkan tanggapan tidak setuju, dan angka empat menunjukkan tanggapan sangat tidak setuju.

\section{PARTISIPASI MEMILIH DAN MEDIA SOSIAL}

Penggunaan media sosial yang dilakukan oleh sebagian besar masyarakat khususnya pemilih pemula telah membuat perubahan keadaan sosial politik di Indonesia. Selain mempengaruhi preferensi pemilih, media sosial juga bisa mempengaruhi partisipasi pemilih. Sebelumnya telah dibahas bahwa partisipasi politik bisa dalam bentuk partisipasi politik konvensional dan non konvensional. Partisipasi dalam kegiatan pemilu merupakan bentuk partisipasi politik bentuk konvensional. Bentuk partisipasi ini sangat dipengaruhi oleh kegiatan calon termasuk kegiatan kampanye yang saat ini sering dilakukan di media sosial. Dengan banyaknya para pemilih pemula yang terbiasa mengakses media sosial menyebabkan kampanye di media sosial bisa meningkatkan partisipasi memilih oleh pemilih pemula. Hal ini bisa dikarenakan ketertarikan para pemilih pemula pada konten kampanye dan pengetahuan mereka tentang politik bertambah sehingga bisa memahami pentingnya ikut berpartisipasi dalam pemilihan umum. 
Kemudian para responden diminta untuk menanggapi tentang pernyataan bahwa Media Sosial efektif dalam meningkatkan partisipasi pemilih pemula pada Pemilu 2019. Hasil penelitian menunjukkan bahwa sebanyak $78,3 \%$ atau sejumlah 47 responden menanggapi dengan tanggapan bersifat mendukung bahwa media sosial efektif dalam meningkatkan partisipasi pemilih pemula pada pemilu 2019. Sementara di kubu kontra terhadap pernyataan tersebut sejumlah $21,7 \%$ atau sejumlah 13 responden. Data tanggapan responden secara lengkap dapat dilihat pada tabel dan diagram berikut ini:

Tabel 6. Partisipasi Memilih dan Media Sosial

\begin{tabular}{|c|c|c|c|c|}
\hline Valid & Frequency & Percent & $\begin{array}{c}\text { Valid } \\
\text { Percent }\end{array}$ & $\begin{array}{c}\text { Cumulative } \\
\text { Percent }\end{array}$ \\
\hline Sangat Setuju & 16 & 26.7 & 26.7 & 26.7 \\
\hline Setuju & 31 & 51.7 & 51.7 & 78.3 \\
\hline Tidak Setuju & 6 & 10.0 & 10.0 & 88.3 \\
\hline Sangat Tidak Setuju & 7 & 11.7 & 11.7 & 100.0 \\
\hline Total & 60 & 100.0 & 100.0 & \\
\hline
\end{tabular}

Diagram 7. Partisipasi Memilih dan Media Sosial

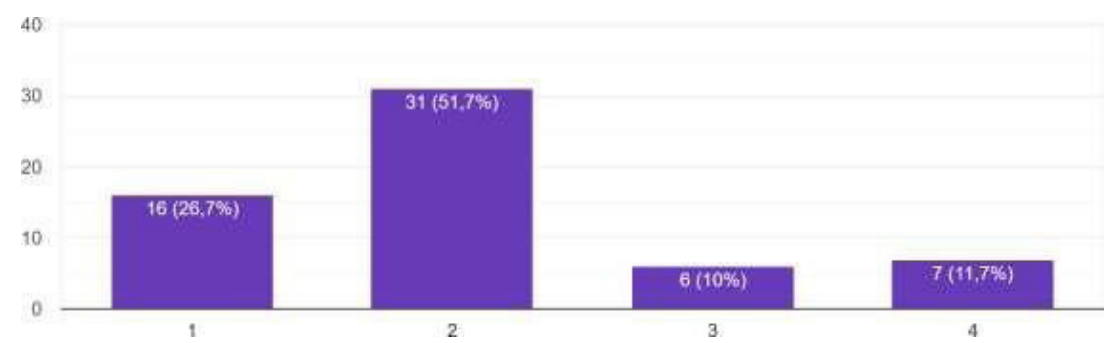


Dari hasil penelitian tersebut tergambar secara jelas bahwa selisih responden yang mendukung pernyataan dan kontra dengan pernyataan cukup jauh. Ini menjadi sebuah bukti bahwa media sosial bisa meningkatkan partisipasi pemilih khususnya pemilih pemula didasarkan pada tanggapan responden. Artinya hal ini menjadi sebuah hal yang positif karena peningkatan partisipasi pemilih bisa menggunakan pemanfaatan media sosial baik oleh pemerintah atau lembaga terkait dalam penyelenggaraan pemilu. Ini merupakan awal yang sangat baik bagi Pemilu di Indonesia. Dengan meningkatnya angka partisipasi pemilih, khususnya para pemilih pemula melalui media sosial, ini akan membuat Pemilu di Indonesia menjadi semakin demokratis kedepannya. Dengan media sosial, tipologi preferensi memilih dari para pemilih juga bergeser dari sebelumnya kebanyakan memilih berdasarkan etnis, ras, dan agama (sosiologis) bisa pelanpelan berganti berdasarkan rasionalitas dari gagasan yang dibawa oleh para calon (psikologis).

\section{MEDIA SOSIAL SEBAGAI RANAH BARU POLITIK}

Peran media sosial menjadi semakin signifikan dengan adanya peningkatan penggunaan internet di Indonesia. Hal ini tentunya berimplikasi pada berbagai ranah, salah satunya ranah politik. Contoh konkrit dengan adanya antusiasme dalam partisipasi politik yang digunakan sebagai ruang yang efektif dalam penyebarluasan kampanye dari pasangan calon dan bahkan berita bohong (hoax) yang ditujukan kepada salah satu calon tertentu. Pada bagian ini, responden diminta 
untuk menanggapi pernyataan bahwa media sosial menjadi ranah baru bagi Calon Presiden dan Wakil Presiden dalam mendapatkan suara dari pemilih pemula. Hasil penelitian menunjukkan bahwa sebanyak $75 \%$ atau sekitar 45 responden mendukung bahwa media sosial mampu menjadi ranah baru bagi pasangan calon dalam mendapatkan suara dari pemilih pemula. Sementara di kubu kontra terhadap pernyataan tersebut sejumlah $25 \%$ atau sejumlah 15 responden.

Tabel 7. Media Sosial sebagai Ranah Baru Politik

\begin{tabular}{|c|c|c|c|c|}
\hline Valid & Frequency & Percent & $\begin{array}{c}\text { Valid } \\
\text { Percent }\end{array}$ & $\begin{array}{c}\text { Cumulative } \\
\text { Percent }\end{array}$ \\
\hline Sangat Setuju & 24 & 40.0 & 40.0 & 40.0 \\
\hline Setuju & 21 & 35.0 & 3.5 .0 & 75.0 \\
\hline Tidak Setuju & 7 & 11.7 & 11.7 & 86.7 \\
\hline Sangat Tidak Setuju & 8 & 13.3 & 13.3 & 100.0 \\
\hline Total & 60 & 100.0 & 100.0 & \\
\hline
\end{tabular}

Diagram 8. Media Sosial sebagai Ranah Baru Politik

30

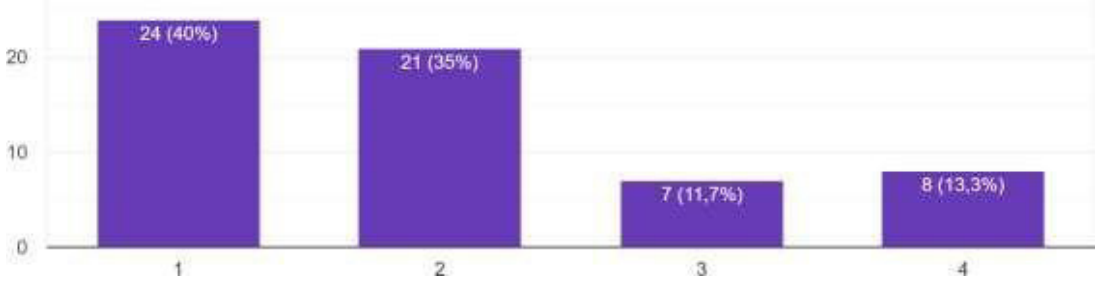


Data di atas membuktikan hadirnya ranah baru dalam sebuah sistem politik, yaitu media sosial. Sekarang pemanfaatan sosial tidak hanya sebagai alat komunikasi, tetapi juga menjadi tempat berlangsungnya kegiatan politik. Tentu ini menjadi kesempatan emas bagi para pasangan calon kedepannya untuk mendapatkan suara dari para pengguna media sosial yang banyak diisi oleh kaum milenial yang notabene para pemilih pemula. Selain itu, hadirnya media sosial sebagai ranah baru dalam aktivitas politik menjadikan semakin luasnya ruang kompetisi pembentukan opini publik. Artinya para pasangan calon harus serius mengelola media sosial mereka jika ingin benarbenar mengambil suara dari para pemilih pemula yang menggunakan media sosial itu sendiri.

\section{KESIMPULAN}

Dari pembahasan tersebut, maka dapat ditarik kesimpulan bahwa media sosial dapat mempengaruhi partisipasi pemilih pemula pada pemilihan presiden 2019. Masifnya kampanye para calon melalui media sosial menimbulkan dampak yang signifikan. Lewat hal tersebut, pemilih pemula dapat mengenal dan mengetahui gagasan yang dibawa para calon. Hal ini dibuktikan dari jawaban responden sejak pertanyaan pertama hingga pertanyaan terakhir yang hampir semuanya merujuk kepada jawaban bahwa media sosial berhasil mempengaruhi partisipasi mereka sebagai partisipasi pemula. Peningkatan partisipasi pemilih juga bisa disebabkan karena adanya media sosial. Keadaan ini dibuktikan pada jawaban responden yang memberikan jawaban berupa dukungan 
bahwa media sosial mampu meningkatkan partisipasi memilih para pemilih pemula. Dengan adanya media sosial, para pemilih khususnya pemilih pemula diharapkan mampu memilih pasangan calon benarbenar karena kampanye yang telah disebarluaskan bukan karena ikutikutan orang saja atau bahkan karena politik uang. Media sosial mampu menjadi titik terang demi terwujudnya Pemilu yang lebih demokratis lagi kedepannya.

Di lain pihak, para pasangan calon juga diharap mampu lebih mengoptimalkan pemanfaatan platform media sosial berbasis internet untuk kepentingan kampanye mereka. Menurut peneliti, kampanye yang diposting di media sosial harus memiliki daya tarik agar dapat menarik perhatian dari para pemilih, khususnya pemilih pemula, misalnya dikemas dalam bentuk video singkat yang diisi dengan slogan serta diberi animasi atau gambar sehingga gampang diingat oleh para pemilih yang melihatnya. Isi pesan politik dalam kampanye pasangan calon juga harus dikemas sesuai dengan karakteristik para pemilih pemula. Hal tersebut dilakukan agar para pemilih pemula dapat mengetahui tentang Pemilu, khususnya informasi pasangan calon dengan aspek yang lebih gampang dan tidak membosankan. 


\section{REFERENSI}

\section{Artikel Jurnal:}

Abidin, Y. Z., Khoerunnisa, R., \& Ma’arif, A. A. (2018). Aktivitas Kampanye Public Relations dalam Mensosialisasikan Internet Sehat dan Aman. Jurnal Ilmu Hubungan Masyarakat, 79-96.

Febriantanto, P. (2019). Analisis Faktor Determinan Peningkatan Partisipasi Politik Penyandang Disabilitas pada Pilkada Kota Yogyakarta 2017. Jurnal Polgov, 157-190.

Harsan, T., Prasetyo, W. D., \& Pujiyana. (2019). Partisipasi Politik Pemilih Pemula Dalam Pemilihan Umum 2019 Di Kelurahan Sumber Kecamatan Banjarsari Kota Surakarta. Civics Education and Social Science Journal (CESSJ), 87-104.

Lukman, S., Priyatna, C. C., \& Sani, A. (2017). Pelatihan Literasi Komunikasi Politik

Pemilih Pemula Sma Darul Hikam Bandung. Jurnal Aplikasi Ipteks untuk Masyarakat, 250-253.

Perangin-angin, L. L., \& Zainal, M. (2018). Partisipasi Politik Pemilih Pemula Dalam Bingkai Jejaring Sosial di Media Sosial. Jurnal ASPIKOM, 737-752.

Rachmat, H. B., \& Esther. (2016). Perilaku Pemilih Pemula Dalam Pilkada Serentak di Kecamatan Ciomas Kabupaten Serang Tahun 2015. Jurnal llmu Pemerintahan Widyapraja, 25-35. 
Subekti, T. (2014). Partisipasi Masyarakat dalam Pemilihan Umum. Journal of Governance and Policy, 01, 1-16.

\section{Artikel Koran Online:}

Koran Sindo. (2017, December 16). Jumlah Pemilih Pemilu 2019 Mencapai 196,5 Juta Orang. nasional.sindonews.com. Diakses dari https://nasional.sindonews.com/berita/1266242/12/jumlahpemilih-pemilu-2019- mencapai-1965-juta-orang

Pertiwi, W. K. (2019, July 20). Hampir Setengah Penduduk Bumi Sudah “Melek” Media Sosial. Diakses dari https://tekno.kompas.com/ $\mathrm{read} / 2019 / 07 / 20 / 16370017 /$ hampir-setengah-penduduk-bumisudah-melek-media-sosial

Winarso, B. (2017, February 3). Jumlah Pengguna Aktif Harian Instagram Sentuh 400 Juta. Retrieved December 17, 2019. Diakses dari https://dailysocial.id/post/jumlah- penggunaharian- instagram 